\title{
Evaluation of dietary intake of lactating women in China and its potential impact on the health of mothers and infants
}

\author{
Haijiao Chen ${ }^{1 \dagger}$, Ping Wang ${ }^{1 \dagger}$, Yaofeng Han ${ }^{1}$, Jing Ma ${ }^{1}$, Frederic A Troy $\|^{1,2}$ and Bing Wang ${ }^{1,3^{*}}$
}

\begin{abstract}
Background: Optimal nutrition for lactating mothers is importance for mother and infants' health and well-being. We determined the nutrient intake and dietary changes during the first 3-month of lactation, and its potential effect on health and disease risk.

Method: Personal interviews were conducted to collect a 24h diet recall questionnaire from 199 healthy lactating women in the postpartum days 2, 7, 30, 90 and healthy 58 non-pregnant women served as the controls.

Results: We found in lactating women (1) the mean daily energy and carbohydrate intake was lower than that of the Chinese Recommended Nutrient Intake (RNI, $2600 \mathrm{Kcal}, 357.5 \sim 422.5 \mathrm{~g}$ ) by $11 \% \sim 17 \%$ and 33\% 49\%,

respectively; (2) the fat intake increased from $3 \%$ to $13 \%$, which was $9 \sim 77 \%$ higher than the RNI (57 86.7g);

(3) the protein intake exceeded the RNI of $85 \mathrm{~g}$ by $32 \sim 53 \%$; (4) the total calories consumed from carbohydrate (39\%-44\%), fat (34\% 42\%) and protein (20\%-23\%) failed to meet Chinese RNI (5) the intake of vitamin C, B1, folate,

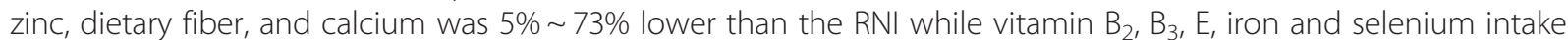
was $20 \%$ to 3 times higher than the RNI. Nutrient intake in the control group was lower for all nutrients than the recommended RNI.

Conclusion: Lactating women on a self-selected diet did not meet the Chinese RNI for many important micronutrients, which may influence the nutritional composition of breast milk and thus impact the potential health of mothers and infants. RNI should consider the regional dietary habits and culture. A single national RNI is not applicable for all of China. Nutritional education into the community is needed.
\end{abstract}

Keywords: Nutrient intake, Lactating women, Chinese RNI and China

\section{Background}

The nutrient intake of lactating women is one of most important determinants of woman's health, well-being and the ability for long-term successful breastfeeding. Human lactation is a natural process, which is well established to provide many healthy benefits for both mothers and their infants. Lactation also has many favourable effects on women, including reducing the incidence of type 2 diabetes, metabolic syndrome [1,2], cardiovascular disease [3,4] and cancer [5]. The nutrient

\footnotetext{
* Correspondence: bing.wang@sydney.edu.au

${ }^{\dagger}$ Equal contributors

'School of Medicine, Xiamen University, Xiamen 300136, China

${ }^{3}$ School of Molecular Bioscience, The University of Sydney, Sydney NSW 2006, Australia

Full list of author information is available at the end of the article
}

intake of lactating women affects the nutrient content of breast-milk and maternal health [6]. As noted, many essential nutrients are secreted into breast milk and represent a significant proportion of nutrient intake in the maternal diet, including docosahexaenoic acid (DHA) [7-9], most vitamins including vitamin B2 [10], vitamin A [11] and vitamin D $[12,13]$. Thus, nutritional requirements for lactating women are higher compared to women who do not breastfeed $[14,15]$.

Perinatal health of the infants are closely linked to the well-being of mothers $[16,17]$. The nutrients that infants receive from breast milk, and the mother's overall physical and mental health during breastfeeding, are all factors that affect the baby's early heath and will continue to influence their health into later life [18]. The 
nutritional content of human breast-milk has been shown to enhance many biochemical and metabolic pathways critical to the development of most organ systems including the digestive, cardiovascular, pulmonary, immune, endocrine and nervous system [19-22]. These metabolic events are vital for maintaining the normal function and health of newborns, particularly those born prematurely or with a low birth weight, and that often persist long after nursing $[19,23]$.

Less definitive information is available on what lactating mothers currently eat and its impact on maternal nutrition and wellness in China. In particular the current prevalence of chronic diseases including obesity, cardiovascular disease, hypertension, diabetes mellitus and a number of other diseases have increased overall in China over pass 30 years rapid economic development [24,25]. Lactating women's nutrient intake is influenced by Westernized lifestyle that is shifting disease patterns at an alarming rate in China towards a profile exceeding that is seen in the more developed countries. It is estimated, for example, that eight of ten deaths in China now result from a chronic disease. In the U.S. this figure is seven out of ten deaths (WHO). Surprising, however, there is little information that systematically evaluates the nutrient intake of lactating women in China during the first three months of lactation. The specific aim of this study was to systematically evaluate the nutrient intake and dietary changes of lactating women in China during the first three months of lactation. We also compared the nutrient intake of lactating women to a control group of non-pregnant and non- lactating woman. We address the major regional and cultural differences in China that makes it difficult to prescribe a "one RNI fits all" recommendation for a country of this size with so many disparate ethnic and cultural groups.

\section{Methods}

Participants were recruited through flyers advertising the study at the Obstetrician's office in the Women's and Children's Hospital, the largest teaching hospitals for healthy women and lactating mothers in Fujian province. One hundred ninety nine healthy and exclusively breastfeeding women aged 23 to 38 years old were initially enrolled in the study beginning on postpartum day two. Of these 199, 195, 196, 173 of the lactating women completed $24 \mathrm{~h}$ food intake recording at 4 time points, representing on days 2, 7, 30 and 90 of lactation, respectively. These four time points are referred to in the text as the "3 month test period", which represents the first 90 days of lactation. A trained and experienced researcher interviewed each participant in their home and recorded the amount and type of food consumed by weighing on a portable digital scale. Participants were provided with a listing of more than 140 food items to be marked in each category on the questionnaire, and to indicate the frequency of daily consumption. The questionnaires served as the basis for determining the intake of basic nutritional components, vitamins, minerals and other dietary supplements. The questionnaires, data collection and quality control procedures are based on China Health and Nutrition Survey guideline and method http://www. cpc.unc.edu/projects/china.

One hundred seventy three of the lactating women completed the $24 \mathrm{~h}$ dietary intake questionnaire for all four-time periods during the 3 months study. Major reasons for women discontinuing the food recording included "they were too busy or tired, time constraints and other family responsibilities". Fifty-eight healthy women were recruited as the control group and collected data once on the 90th day of data collection for the lactating women. The selection criteria for the healthy women were non-pregnant, non- lactating and not on any medications. The control and lactating women were instructed not to change their dietary or physical activity during the study. The $24 \mathrm{~h}$ diet intake questionnaire for the control subjects was collected and analyzed in the identical way as the test group of lactating mothers. All participants' information and food intake was registered in a computer database. The study protocol was approved by the Human Ethics Committee of Xiamen University. All invited participants provided written informed consent before inclusion in the study.

The food intake were analysed by trained researchers using the China Food Composition to calculate individual nutrient intakes of the 1506 different foods and 31 nutrients [26]. Energy and selected nutrient intakes were analyzed using Software for "Intake Distribution Estimation" based on Chinese food nutrition composition $[14,15]$. The general characteristics of subjects during the 3 months test period that were used to calculate individual nutrient intakes are summarised in Table 1.

Data were analyzed statistically by two-factor repeated measures ANOVA model for the four time periods, using the Greenhouse-Geisser adjustment for asphericity for the lactating women. Comparisons between lactating women at the four time periods and the normal control group of women were made using a multivariate general linear model for the components of selected nutrients (protein, fat, vitamins etc.), with adjustment for BMI as a covariate. All analyses were completed by using SPSS for Macintosh 19. (SPSS Inc., Chicago). The significance level was set at $\mathrm{P}<0.05$, and for multiple comparisons, $\mathrm{P}<0.01$.

\section{Results \\ Subjects}

There was no significant difference in age, ethic group, education, smoking, alcohol consumption and family 
Table 1 General characteristics of study participants ${ }^{1}$

\begin{tabular}{|c|c|c|c|c|c|}
\hline & & Lact & vomen & & Controls \\
\hline & 2nd day $(n=199)$ & 7th day $(n=195)$ & 30th day $(n=196)$ & 90th day $(n=173)$ & $(n=58)$ \\
\hline Age (yrs) & & & & & \\
\hline$-20-25$ & 47 & 44 & 36 & 39 & 4 \\
\hline$-26-30$ & 125 & 124 & 129 & 112 & 36 \\
\hline$-31-35$ & 26 & 26 & 30 & 21 & 16 \\
\hline$->35$ & 1 & 1 & 1 & 1 & 2 \\
\hline Height (cm) & $160.2 \pm 4.2$ & $160.4 \pm 4.1$ & $160.1 \pm 4.3$ & $159.9 \pm 4.0$ & $159.0 \pm 3.5$ \\
\hline Weight (kg) & $60.1 \pm 6.4^{b}$ & $59.1 \pm 6.6^{b}$ & $58.6 \pm 6.7^{b}$ & $58.9 \pm 5.5^{b}$ & $52.9 \pm 3.8^{\mathrm{a}}$ \\
\hline $\mathrm{BMI}\left(\mathrm{kg} / \mathrm{M}^{2}\right)$ & $23.4 \pm 2.0^{\mathrm{b}}$ & $22.9 \pm 2.2^{b}$ & $22.8 \pm 2.1^{b}$ & $23.0 \pm 1.9^{b}$ & $20.9 \pm 1.1^{\mathrm{a}}$ \\
\hline First child & Yes & Yes & Yes & Yes & N/A \\
\hline Residence & & & & & \\
\hline - Local & 186(93.5) & 185(94.9) & 187(95.4) & 168(97.1) & $55(94.8)$ \\
\hline - Immigrant & $13(6.5)$ & $10(5.1)$ & $9(4.6)$ & $5(4.8)$ & $3(5.2)$ \\
\hline Ethnic group & & & & & \\
\hline - Han & 195(98.2) & 189(97.1) & 186(95.0) & 173(100) & $56(96.6)$ \\
\hline - Others & $4(1.8)$ & $6(2.9)$ & $10(5.0)$ & 0 & $2(3.4)$ \\
\hline Education & & & & & \\
\hline - Middle school & $25(12.5)$ & $15(7.5)$ & $20(10.0)$ & $23(13.3)$ & $7(11.9)$ \\
\hline - High school & $49(24.6)$ & $47(23.9)$ & $34(17.5)$ & $69(40.0)$ & $14(24.3)$ \\
\hline - College & $60(30.2)$ & $78(40.2)$ & $78(40.0)$ & $46(26.7)$ & $16(27.6)$ \\
\hline - University & $65(32.7)$ & $55(28.4)$ & $64(32.5)$ & $35(20.0)$ & $21(36.2)$ \\
\hline Smoking & never & never & never & never & never \\
\hline Drinking & never & never & never & never & occasionally \\
\hline Regular exercise & no & no & yes & yes & yes \\
\hline Medication & no & no & no & no & no \\
\hline
\end{tabular}

${ }^{1}$ Values (mean \pm SD) in the same row with different superscript letters $(a, b)$ denotes a significant different, $P<0.01$. Bonferroni adjustment for multiple comparisons of the lactating women compared with the control group of women and a repeated measures analysis of Greenhouse-Geisser adjustment for asphericity for 4 different time points comparison of the lactating women.

social status between lactating and control women in the study. The mean body mass index (BMI) of the lactating mothers were within the normal range of $22.8 \sim 23.4$ $( \pm 1.9 \sim 2.2)$ and did not change significantly during the first 3 months of lactation. The mean BMI $(20.9 \pm 1.1)$ for the control group of women was also in the normal range for the recommended Chinese BMI [27,28] and was $9 \% \sim 10 \%$ lower than that of lactating women. The difference in BMI between lactating and control women was highly significant $(\mathrm{P}<0.001)$, as shown in Table 1 .

\section{Consumption of food groups}

The mean intake of food groups (g/day) in the lactating and control women during the first 3 months lactation is shown in Table 2. The rank orderings of mean intake for the food groups from high to low in lactating women were animal food, cereals, vegetables, fruits, dairy products, legumes/legumes products, nuts/ seeds, fungi and algae. The mean intake of total calories in animal food, flour and flour products in lactating women, showed a significant decrease over time $(P<0.005)$, when the full data set of 199 women was analyzed or in the 173 women who completed the 4 time-points of the study when analysed separately (Table $2 \mathrm{P}<0.01 \sim 0.001$ ). On the $90^{\text {th }}$ day of lactation, $\sim 74 \% \sim 80 \%$ of the total dietary calories, $85 \% \sim 96 \%$ of the animal food, and $20 \% \sim 42 \%$ of the flour and flour products remained at the level found during the first month of lactation. However, the mean intake of vegetables, nuts/seeds, fungi, algae, rice/rice products, dairy products, legumes/legumes products and root and tubers showed a significant increase over time, for the 173 lactating women who had completed the study (Table 2, $\mathrm{P}<0.005 \sim 0.0001$ ). Also the intake of most food categories in the control group of women was lower than in the lactating women at all four time periods, either before or after the BMI was adjusted as a covariant $(\mathrm{P}<0.005 \sim 0.0001$, Table 2$)$, exceptions were 
Table 2 The mean intake of food groups (g/day) during the first 90 days lactation ${ }^{1}$

\begin{tabular}{|c|c|c|c|c|c|c|}
\hline \multirow[b]{2}{*}{ Food categories } & \multicolumn{4}{|c|}{ Lactating women } & \multirow{2}{*}{$\frac{\text { Controls }}{(n=58)}$} & \multirow[b]{2}{*}{ Common varieties } \\
\hline & $\begin{array}{l}\text { 2nd day } \\
(n=199)\end{array}$ & $\begin{array}{l}\text { 7th day } \\
(n=195)\end{array}$ & $\begin{array}{l}\text { 30th day } \\
(n=196)\end{array}$ & $\begin{array}{l}\text { 90th day } \\
(n=173)\end{array}$ & & \\
\hline Pure Calories & $57 \pm 4^{b}$ & $59 \pm 3^{b}$ & $54 \pm 3^{\mathrm{ab}}$ & $44 \pm 2^{\mathrm{ac}}$ & $33 \pm 1^{c}$ & Oil, brown sugar, chocolate \\
\hline Animal Food & $605 \pm 25^{a b}$ & $659 \pm 20^{a b}$ & $683 \pm 23^{b}$ & $580 \pm 15^{a}$ & $378 \pm 22^{c}$ & $\begin{array}{l}\text { Pork, beef, fish, Chicken, } \\
\text { clam, duck, harslet }\end{array}$ \\
\hline Nuts/seeds & $8 \pm 2^{b}$ & $13 \pm 3^{\mathrm{ab}}$ & $12 \pm 2^{\mathrm{ab}}$ & $19 \pm 2^{\mathrm{a}}$ & $1 \pm 1^{b}$ & Peanuts, kernels, sesame \\
\hline Vegetables & $99 \pm 8^{b}$ & $123 \pm 7^{b}$ & $183 \pm 8^{\mathrm{a}}$ & $218 \pm 7^{\mathrm{a}}$ & $202 \pm 11^{\mathrm{a}}$ & $\begin{array}{l}\text { Lettuce, cabbage, Bok choy, } \\
\text { tomatoes, kidney bean }\end{array}$ \\
\hline Fungi and algae & $7 \pm 2^{a}$ & $7 \pm 1^{a}$ & $10 \pm 2^{\mathrm{a}}$ & $18 \pm 2^{b}$ & $7 \pm 3^{a}$ & $\begin{array}{l}\text { agrocybe aegerita, lentinus } \\
\text { edodes }\end{array}$ \\
\hline Fruits & $138 \pm 17$ & $118 \pm 11$ & $164 \pm 12$ & $158 \pm 8$ & $127 \pm 12$ & $\begin{array}{l}\text { Apple, banana, lichee, longan, } \\
\text { red date }\end{array}$ \\
\hline Cereals & $335 \pm 16^{\mathrm{bc}}$ & $355 \pm 12^{b}$ & $401 \pm 10^{a}$ & $409 \pm 8^{a}$ & $293 \pm 13^{c}$ & \\
\hline - Rice and rice products & $270 \pm 16^{a}$ & $287 \pm 11^{\mathrm{a}}$ & $335 \pm 11^{\mathrm{b}}$ & $364 \pm 8^{b}$ & $261 \pm 16^{a}$ & Rice, rice noodles \\
\hline - Flour and flour products & $126 \pm 13^{b}$ & $89 \pm 9^{c}$ & $59 \pm 6^{\mathrm{cd}}$ & $25 \pm 4^{\mathrm{a}}$ & $24 \pm 5^{\mathrm{ad}}$ & Steamed bread, noodles \\
\hline - Other cereals & $15 \pm 4^{\mathrm{ab}}$ & $16 \pm 4^{\mathrm{ab}}$ & $7 \pm 2^{\mathrm{ab}}$ & $19 \pm 3^{b}$ & $0.4 \pm 0.4^{a}$ & $\begin{array}{l}\text { Millet, glutinous rice, coix } \\
\text { seed }\end{array}$ \\
\hline $\begin{array}{l}\text { Legumes/legumes } \\
\text { products }\end{array}$ & $18 \pm 3^{b}$ & $21 \pm 4^{\mathrm{ab}}$ & $31 \pm 6^{\mathrm{ab}}$ & $39 \pm 7^{a}$ & $50 \pm 12^{a}$ & Soybean, soybean milk \\
\hline Dairy products & $29 \pm 6^{b}$ & $42 \pm 7^{b}$ & $95 \pm 12^{a}$ & $119 \pm 10^{\mathrm{a}}$ & $39 \pm 12^{b}$ & Milk, powdered milk \\
\hline Root and tubers & $0.4 \pm 0.3^{\mathrm{a}}$ & $0.4 \pm 0.3^{\mathrm{a}}$ & $4 \pm 2^{\mathrm{a}}$ & $16 \pm 3^{\mathrm{b}}$ & $0 \pm 0^{\mathrm{a}}$ & Potato, carrots \\
\hline
\end{tabular}

${ }^{1}$ Values (mean \pm SE) in the same row with different superscript letters ( $a, b, c, d$ ) are significantly different $P<0.05 \sim 0.0001$, Bonferroni adjustment for multiple comparisons of the lactating women compared with the control group of women and a repeated measures analysis of Greenhouse-Geisser adjustment for asphericity for 4 different time points comparison of the lactating women.

vegetables, fruits and legumes and legumes products. However, the mean intake value for animal food in the control group of women was $\sim 35 \%$ to $45 \%$ lower than the lactating women throughout the 3 mo studies $(P<0.0001$ Table 2).

The rank of animal food intake in lactating women from high to low was meat and meat products (29\% 35\%), fish/shellfish and seaweeds products
(19\% 23\%), poultry $(6 \% \sim 11 \%)$, eggs $(7 \% \sim 9 \%)$, and milk/milk products $(1 \% \sim 3 \%)$ (Table 3$)$. The intake of meat and meat products and fish/shellfish decreased during the course of lactation, while the consumption of milk and milk products increased. The control group of women had a similar pattern of animal food intake as the lactating women, except that egg intake was higher than poultry and poultry products (Table 3 ). In lactating

Table 3 Mean animal food intake (g/day) and the percentage of protein intake from different protein sources in lactating and control group of women ${ }^{1}$

\begin{tabular}{|c|c|c|c|c|c|c|c|c|c|c|}
\hline & \multicolumn{8}{|c|}{ Lactating women } & \multirow{2}{*}{\multicolumn{2}{|c|}{$\begin{array}{c}\text { Controls } \\
(n=58)\end{array}$}} \\
\hline & \multicolumn{2}{|c|}{ 2nd day $(n=199)$} & \multicolumn{2}{|c|}{ 7th day $(n=195)$} & \multicolumn{2}{|c|}{ 30th day $(n=196)$} & \multicolumn{2}{|c|}{ 90th day $(n=173)$} & & \\
\hline & Intake & $\%$ protein & Intake & $\%$ protein & Intake & $\%$ protein & Intake & $\%$ protein & Intake & $\%$ protein \\
\hline Meat and meat products & $242 \pm 17^{b}$ & $30.7 \pm 1.5^{a b}$ & $227 \pm 14^{a b}$ & $29.1 \pm 1.4^{\mathrm{ab}}$ & $225 \pm 11^{a b}$ & $29.9 \pm 1.3^{b}$ & $226 \pm 10^{a b}$ & $34.6 \pm 1.3^{\mathrm{ac}}$ & $175 \pm 12^{a}$ & $41.2 \pm 2.2^{c}$ \\
\hline $\begin{array}{l}\text { Poultry and poultry } \\
\text { products }\end{array}$ & $89 \pm 13^{a b}$ & $6.7 \pm 1.1^{\mathrm{ab}}$ & $130 \pm 14^{b}$ & $10.6 \pm 1.2^{b c}$ & $110 \pm 12^{b}$ & $10.1 \pm 1.0^{c}$ & $53 \pm 7^{a}$ & $6.0 \pm 0.8^{\mathrm{ab}}$ & $24 \pm 6^{a}$ & $4.0 \pm 1.1^{\mathrm{a}}$ \\
\hline Milk and milk products & $29 \pm 6^{b}$ & $1.0 \pm 0.2^{a}$ & $42 \pm 7^{b}$ & $1.1 \pm 0.2^{\mathrm{a}}$ & $95 \pm 12^{a}$ & $2.2 \pm 0.3^{c}$ & $119 \pm 10^{a}$ & $3.2 \pm 0.3^{d}$ & $39 \pm 12^{b}$ & $0.9 \pm 0.4^{\mathrm{ac}}$ \\
\hline Eggs & $69 \pm 6^{a b}$ & $7.5 \pm 0.7^{\mathrm{ab}}$ & $88 \pm 6^{b}$ & $9.4 \pm 0.7^{b}$ & $79 \pm 4^{b}$ & $8.3 \pm 0.5^{\mathrm{ab}}$ & $59 \pm 3^{a}$ & $6.8 \pm 0.4^{\mathrm{ac}}$ & $29 \pm 4^{c}$ & $4.6 \pm 0.8^{c}$ \\
\hline $\begin{array}{l}\text { Fish/shellfish } \\
\text { products }\end{array}$ & $176 \pm 15^{b}$ & $23.0 \pm 1.7$ & $172 \pm 12^{a b}$ & $21.4 \pm 1.4$ & $176 \pm 11^{b}$ & $21.5 \pm 1.3$ & $124 \pm 9^{a}$ & $19.1 \pm 1.3$ & $118 \pm 9^{a b}$ & $22.7 \pm 1.7$ \\
\hline
\end{tabular}

${ }^{1}$ Values (mean \pm SE) in the same row with different superscript letters $(a, b, c)$ are significantly different $(P<0.05 \sim 0.0001)$. Bonferroni adjustment for multiple comparisons of the lactating women compared with the control group of women $(P<0.01)$ and a repeated measures analysis of Greenhouse-Geisser adjustment for asphericity for 4 different time points comparison for the lactating women. 
women, the total animal food intake contributed about $70 \%$ of the total protein consumption throughout the first 3 months of lactation (Table 3). Similar to the lactating women, $73 \%$ of the protein intake of the control women came from animal food. Significantly, more than $20 \%$ of the protein was from fish/shellfish and seaweed products in both lactating and control group of woman. The overall mean intake of different protein sources was lower in the control women compared to the lactating women either before or after the BMI was adjusted as a covariant (Table $3, P<0.01 \sim 0.0001$ ).

\section{Energy and selected nutrient intake}

The mean energy and selected nutrient intake of lactating women and the control group of women is shown in Table 4. In the 173 lactating women, the mean energy intake did not change significantly over time (Table 4, $\mathrm{P}>0.05$ ), but the level of energy intake was $11 \% \sim 17 \%$ lower than that recommended by the Chinese RNI $(2,600 \mathrm{kcal} /$ day $)$ at the four different time points. The control group of women had a $38 \%$ lower mean energy intake than that recommended by the RNI for a moderate level of physical activity $(2,300 \mathrm{Kcal} /$ day $)$. Lactating women had about a $35 \%$ higher energy intake than the control group throughout the 3 month study $(P<0.05 \sim 0.001)$, whether justified for BMI as a covariant or not.

As shown in Tables 4, the mean intake of dietary carbohydrate in lactating women and the control group of women only consumed $61 \sim 67 \%$ and $43 \%$ of their RNI respectively. These values are based on the lowest recommended RNI of $357.5 \mathrm{~g}$ for lactating women and $316.3 \mathrm{~g}$ for health adult control women with moderate physical activity. Based on the highest intake level of dietary carbohydrate for the Chinese RNI $422.5 \mathrm{~g}$ for lactating women and 373.8 for the control group, both groups of women consumed only $51 \% \sim 57 \%$ and $37 \%$ of the recommended values throughout 3 months study, respectively. Carbohydrate consumption contributed $39 \%$ to $44 \%$ of the total energy in lactating women during first 3 months lactation and $38 \%$ in the control group (Table 4).

Table 4 Mean energy (Kcal) and selected nutrients intake in lactating women during the first 90 days of lactation and the controls ${ }^{1}$

\begin{tabular}{|c|c|c|c|c|c|c|c|}
\hline & & & tating women & & & Cont & \\
\hline & $\begin{array}{l}\text { RNI for lactating } \\
\text { Women }\end{array}$ & $\begin{array}{l}2^{\text {nd }} \text { day } \\
(n=199)\end{array}$ & $\begin{array}{c}7^{\text {th }} \text { day } \\
(n=195)\end{array}$ & $\begin{array}{l}30^{\text {th }} \text { day } \\
(\mathrm{n}=196)\end{array}$ & $\begin{array}{l}90^{\text {th }} \text { day } \\
(\mathrm{n}=173)\end{array}$ & $\begin{array}{l}{ }^{2} \mathrm{RNI} \text { for normal } \\
\text { women }\end{array}$ & $(n=58)$ \\
\hline Energy (kcal) & 2600 & $2152 \pm 52^{b}$ & $2306 \pm 49^{b}$ & $2282 \pm 36^{b}$ & $2202 \pm 28^{b}$ & 2300 & $1431 \pm 54^{a}$ \\
\hline Protein (g) & 85 & $118.2 \pm 4.0^{b c}$ & $130.0 \pm 3.2^{b}$ & $126.2 \pm 2.7^{b}$ & $111.6 \pm 2.0^{c}$ & 70 & $80.1 \pm 3.5^{\mathrm{a}}$ \\
\hline Fat (g) & $57.8 \sim 86.7^{3}$ & $80.9 \pm 2.7^{b}$ & $94.8 \pm 2.9^{c}$ & $96.8 \pm 2.3^{c}$ & $102.5 \pm 2.0^{c}$ & $51.1 \sim 76.73$ & $64.3 \pm 2.5^{a}$ \\
\hline Carbohydrate (g) & $357.5 \sim 422.5^{4}$ & $238.4 \pm 8.9^{b}$ & $240.0 \pm 8.2^{b}$ & $234.9 \pm 5.8^{b}$ & $216.9 \pm 3.8^{b}$ & $316.3 \sim 373.84$ & $136.8 \pm 6.8^{\mathrm{a}}$ \\
\hline Dietary fiber (g) & 30.2 & $8.2 \pm 0.6^{a}$ & $10.4 \pm 0.9^{\mathrm{ab}}$ & $10.3 \pm 0.5^{b c}$ & $14.0 \pm 0.6^{d}$ & 30.2 & $7.8 \pm 0.6^{\mathrm{ac}}$ \\
\hline Vitamin $A\left(\mu g R E^{5}\right)$ & 1200 & $1620 \pm 173^{b}$ & $1304 \pm 142^{b c}$ & $1146 \pm 129^{c d}$ & $734 \pm 60^{\mathrm{ad}}$ & 700 & $255 \pm 85^{a}$ \\
\hline Thiamine (mg) & 1.8 & $1.5 \pm 0.07^{\mathrm{b}}$ & $1.5 \pm 0.06^{b}$ & $1.6 \pm 0.05^{b}$ & $1.7 \pm 0.05^{b}$ & 1.3 & $1.2 \pm 0.07^{\mathrm{a}}$ \\
\hline Riboflavin (mg) & 1.7 & $2.9 \pm 0.17^{b d}$ & $3.2 \pm 0.14^{b}$ & $2.7 \pm 0.11^{b c}$ & $2.5 \pm 0.11^{c d}$ & 1.2 & $1.3 \pm 0.10^{\mathrm{a}}$ \\
\hline Niacin (mg) & 18 & $37.7 \pm 1.84^{\mathrm{b}}$ & $42.7 \pm 1.48^{b}$ & $37.8 \pm 1.10^{\mathrm{b}}$ & $32.5 \pm 0.75^{c}$ & 13 & $21.4 \pm 0.85^{\mathrm{a}}$ \\
\hline Vitamin C (mg) & 130 & $59.1 \pm 5.61^{\mathrm{a}}$ & $68.7 \pm 3.94^{\mathrm{ab}}$ & $77.1 \pm 4.09^{b}$ & $96.6 \pm 4.44^{c}$ & 100 & $68.3 \pm 3.98^{\mathrm{ab}}$ \\
\hline Vitamin E (mg) & 14 & $41.3 \pm 1.36$ & $45.0 \pm 3.21$ & $41.1 \pm 1.12$ & $40.4 \pm 1.15$ & 14 & $39.3 \pm 0.84$ \\
\hline Folate $\left(\mu \mathrm{g} \mathrm{DFE}^{6}\right)$ & 500 & $441.6 \pm 20.3^{b}$ & $455.2 \pm 16.5^{b}$ & $470.0 \pm 18.8^{b}$ & $441.1 \pm 29.3^{b}$ & 400 & $286.8 \pm 15.8^{a}$ \\
\hline Calcium (mg) & 1200 & $428 \pm 22^{\mathrm{a}}$ & $454 \pm 18^{a}$ & $595 \pm 22^{b}$ & $544 \pm 17^{b}$ & 800 & $404 \pm 19^{a}$ \\
\hline Iron(mg) & 25 & $34.7 \pm 1.4^{b}$ & $37.7 \pm 1.3^{b}$ & $34.8 \pm 1.0^{b}$ & $30.0 \pm 0.7^{c}$ & 20 & $21.6 \pm 0.9^{a}$ \\
\hline Zinc (mg) & 21.5 & $18.99 \pm 0.79^{b}$ & $20.8 \pm 0.77^{b}$ & $20.4 \pm 0.59^{b}$ & $21.3 \pm 0.59^{b}$ & 11.5 & $14.49 \pm 0.68^{a}$ \\
\hline Selenium ( $\mu \mathrm{g})$ & 65 & $145.3 \pm 9.4^{b c}$ & $163.0 \pm 7.3^{c}$ & $131.4 \pm 5.8^{b}$ & $97.8 \pm 4.6^{\mathrm{a}}$ & 50 & $72.7 \pm 5.8^{\mathrm{a}}$ \\
\hline lodine $(\mu \mathrm{g})$ & 200 & $162.2 \pm 5.5^{b}$ & $220.7 \pm 11.8^{c}$ & $214.6 \pm 11.2^{c}$ & $248.3 \pm 15.7^{c}$ & 150 & $200.3 \pm 16.5^{b c}$ \\
\hline DHA (g) & & $0.24 \pm 0.03^{\mathrm{ab}}$ & $0.29 \pm 0.03^{b}$ & $0.24 \pm 0.02^{a b}$ & $0.17 \pm 0.01^{a}$ & & $0.13 \pm 0.02^{a}$ \\
\hline
\end{tabular}

Values (mean \pm SE) in the same row with different superscript letters $(a, b, c, d)$ are significantly different, $(P<0.05 \sim 0.0001)$. Bonferroni adjustment for multiple comparisons of the lactating women compared with the control group of women $(P<0.01)$ and a repeated measures analysis of Greenhouse-Geisser adjustment for asphericity for 4 different time points comparison of the lactating women.

${ }^{2} \mathrm{RNI}$ 's for control women are for a moderate level of physical activity.

${ }^{3}$ Conversion based on the Chinese RNI for fat providing 20\% 30\% of the total energy per day.

${ }^{4}$ Conversion based on the Chinese RNI for carbohydrate providing 55\% 65\% of the total energy per day.

${ }^{5} \mathrm{RE}$ : retinol equivalent.

${ }^{6}$ DFE: dietary folic acid equivalent. 
The mean fat intake of lactating women ranged from $29 \%$ to $44 \%$ higher than that of the lowest recommended levels of the RNI (57.8g/day) during the first 3 months of lactation, and $\sim 10 \%$ greater than the highest level of the RNI $(86.7 \mathrm{~g} /$ day $)$ during the last 3 time periods of lactation (Table 4). Fat consumption contributed $\sim 34 \% \sim 42 \%$ of the total energy during the first 3 months of lactation. On lactation day 90, dietary fat, but not carbohydrate was the predominant source of energy. In the control group of women however, the main energy intake was fat (40\%) and then carbohydrate (38\%). The Chinese Dietary Guidelines [15,29] recommends the distribution of energy intake from three important nutrients as carbohydrate 55\% 65\%, fat $20 \% \sim 30 \%$, and protein $10 \sim 15 \%$. Thus, the lactating and control group of women had a higher proportion of fat and lower proportion of carbohydrate intake than that recommended by the Chinese RNI $[14,15]$.

As shown in Tables 4, lactating mothers consumed $31 \%$ to $53 \%$, more protein than the RNI recommended level $(85 \mathrm{~g} /$ day) during the first 3 months of lactation. The highest protein intake was in lactating day 7 and 30 and lowest was in the lactating day 90. Overall difference between the 4 time-points of lactation was significant when all the data available were included in the analysis or for the 173 lactating women who had completed data sets were analyzed separately $(\mathrm{P}<0.05$, Table 4$)$. The mean protein intake in the control group of women was $14 \%$ higher than the RNI (70g), however these levels were $25 \sim 38 \%$ lower than that of lactating mothers throughout the 3 months of lactation, whether adjusted or not for the BMI $(\mathrm{P}<0.0001)$. The mean protein intake from animal food contributed $69 \sim 72 \%$ and $73 \%$ of total protein in the lactating and control group of women, respectively. Furthermore, there was greater than a 2 to 5 -fold higher intake of poultry, eggs, milk and milk products in lactating mothers than in the control group of women $(\mathrm{P}<0.0001$, Table 3$)$, whether adjusted for the BMI or not.

\section{Intake levels of selected vitamins and minerals}

As shown in Table 4, the mean total dietary intake of vitamins and minerals from foods in the lactating women were lower than that recommended by the Chinese RNI ranging from $26 \% \sim 55 \%$ lower for vitamin C, $4 \% \sim 17 \%$ lower for thiamine, $6 \% \sim 12 \%$ lower for folic acid, $50 \% \sim 65 \%$ lower for calcium and 1\% 12\% lower for zinc during the first 3 months of lactation. Of particular concern for the well being of the mother, and possibly the infant, was the low level of intake of vitamin $\mathrm{C}$, folate and calcium. In contrast, there were elevated levels of intake above the RNI for riboflavin (48\% 87\% higher), niacin ( 2-fold higher), vitamin E ( 3-fold higher), iron (20\% 50\% higher) and selenium (1.5 2.5- fold higher). In lactating mothers, the mean intake of vitamin A, riboflavin, selenium, DHA and iron decreased during the course of lactation, while vitamin $C$ and iodine increased. There was no significant change in the mean intake of vitamin B1, vitamin E, folic acid and zinc during the 3 months of lactation. In the control group of women, however, there was a low intake of vitamin A (36\%), thiamine (92\%), vitamin C (68\%), folate (72\%) and calcium (51\%), compared to the recommended RNI. The intake of all vitamins and minerals were lower in the control group of women compared to the lactating mothers, in particular for thiamine, riboflavin, niacin, folic acid, iron and zinc during the first 3 months of lactation, whether adjusted for the BMI or not $(\mathrm{P}<0.001)$. Also, the lactating and control group of women consumed only $27 \% \sim 46 \%$ and $26 \%$ of the amount of dietary fiber recommended by the RNI ( $30.2 \mathrm{~g} /$ day), respectively.

\section{Discussion}

The $24 \mathrm{~h}$ dietary recall questionnaire is widely used as a tool for assessing food consumption, despite disagreements about its validity to accurately assess an individual's mean intake (5-8). In this study, to circumvent this possible limitation, trained personnel visited each lactating mother in their homes on four occasions during the first three months of lactation, and recorded all food items they consumed. Our new findings showed that total energy and the mean intake of carbohydrate was $12-15 \%$ and $33 \sim 49 \%$ lower than the Chinese recommended RNI and protein and fat in lactating mothers ranged from $31 \sim 53 \%$ and $9-77 \%$ higher than the Chinese RNI respectively. Interestingly, the control group of women had similar nutrient intake patterns of lower energy (38\%), lower carbohydrate $(57 \% \sim 63 \%)$ and higher levels of protein (14\%) than that recommended by the RNI for the moderate physical activity level of an adult. Thus, the main nutrient intake of both lactating mothers and the control group of women fails to meet Chinese RNI.

The energy needs of a breastfeeding mother are increased because of milk production. Our findings showed that the mean daily energy intake of lactating mothers was $720 \sim 850 \mathrm{kcal}$ higher than that of control woman during the first 90 days of lactation. Also the distribution of total calories from carbohydrate, 39\% 44\%, protein, $20 \% \sim 23 \%$ and fat, $34 \% \sim 42 \%$ did not meet the recommended level of energy distribution (Figure 1). Interestingly the control group of women had similar energy distribution pattern as lactating women (Figure 1). Thus, the distribution of calories derived from the 3 major nutrients failed to meet a balanced diet as recommended by the Chinese RNI for both lactating and the control group of women (Figure 1). 


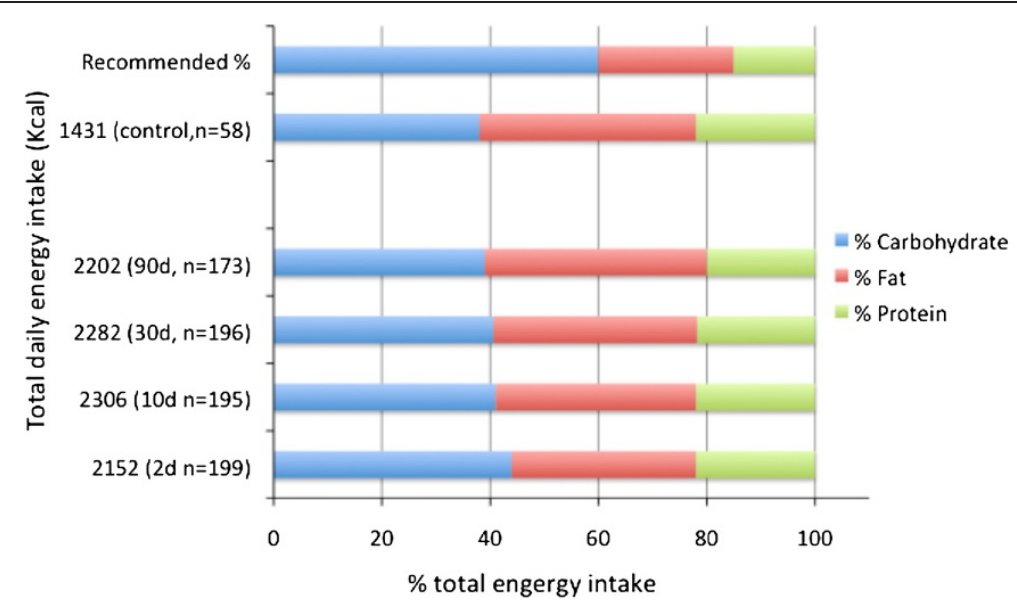

Figure 1 Daily energy intake distribution from carbohydrate, fat, and protein ${ }^{1}$. 'The recommended distribution of daily energy intake in China is carbohydrates 55\% 65\%, protein 12\% 16\% and fat 20\% 30\% respectively. The figure constructed using the media figure of the recommend levels of daily energy intake distribution from carbohydrates $60 \%$, protein $15 \%$ and fat $25 \%$.

Lactating women have an increased requirement for dietary protein intake for synthesis of the protein in breast milk, and for the growth, maintenance and repair of cells. As shown in Table 4, lactating mothers consumed 31\% 53\% more protein than required by the Chinese RNI. Based on their body weight, this increased level of protein intake showed little change during the first 3 months of lactations, ranging from $\sim 1.89 \mathrm{~g} / \mathrm{kg}$ to $2.2 \mathrm{~g} / \mathrm{kg}$, which was higher than the $1.1 \mathrm{~g} / \mathrm{kg}$ reference daily intake (RDI) for lactating women in developed country e.g. Australia [30]. The comparative value for the control group of women was $1.51 \mathrm{~g} / \mathrm{kg}$, which was higher than the $0.75 \mathrm{~g} / \mathrm{kg}$ recommended for $20 \sim 40$ yearold non-pregnant women [30]. The American Heart Association does not recommend high protein diets because they may restrict healthy foods that provide essential nutrients and do not provide the variety of foods needed to adequately meet nutritional needs [31]. While these diets may not be harmful for most healthy adults for short periods of time there are, to our knowledge, no long-term scientific studies to support their overall efficacy and safety [31]. In particular, when high protein intake exceeds the body's needs, this may place an individual at higher risk for kidney and liver disorders, osteoporosis and reduced vitamins, minerals, fiber and the uptake of other nutritional elements. All of these factors may thus lead to other potential health risks.

Although lactating women consumed $\sim 70 \%$ of their protein from animal products, which is also a source of other essential nutrients, the animal foods usually contain a high content of saturated fatty acid (SFA's). The consumption of a diet rich in SFA's for a sustained period raises the risk of coronary heart disease (CHD), diabetes, stroke and several types of cancer [31]. The lactating group mothers consumed $9 \sim 77 \%$ more fat than the recommended level in China (Table 3-4). However, these lactating women consumed a diet higher in fish/ shellfish and seaweed products $(124 \sim 176 \mathrm{~g} /$ day $)$, which was higher than the recommended RNI $(50 \sim 100 \mathrm{~g} /$ day $)$ [14]. Fish/shellfish are an important source of trace minerals, including iodine and selenium and long chain polyunsaturated fatty acid, e.g. DHA [32]. Fish are also a major source of vitamin D, which through neurotrophic, anti-inflammatory, and neuroprotective effects, may work synergistically with DHA to protect the brain [33]. DHA intake in lactating group women remained relatively constant during the first 3 month of lactation, ranging from $\sim 290 \mathrm{mg} /$ day at day 7 to $\sim 170 \mathrm{mg} /$ day at day 90 of lactation. This level is similar to that in the developed country e.g. $\sim 160 \mathrm{mg} /$ day in Australia [30] and is higher than the general population in China, which is about $22.1 \mathrm{mg} /$ day in urban and $6.0 \mathrm{mg} / \mathrm{d}$ rural area [34]. Recent studies have shown that the replacement of only $1 \%$ of energy from SFAs with polyunsaturated fatty acids (PUFAs) lowers cholesterol levels in the serum lowdensity lipoprotein (LDL), resulting in a reduction in the incidence of CHD by $\geq 2-3 \%$ [35]. Thus, the relatively high level of DHA intake in the lactating mothers may translate into a reduced risk of $\mathrm{CHD}$, and it will be interesting to determine if long-term epidemiological studies validates this supposition.

It was unanticipated to find that lactating women during their first 3 months of lactation had 33\% 49\% lower carbohydrate intake than that recommended by Chinese RNI (Table 4). The mean carbohydrate intake from cereals during the first 90 days of lactation was only $335 \mathrm{~g} /$ $\mathrm{d} \sim 409 \mathrm{~g} / \mathrm{d}$ (Table 2 ). The variety of cereals included mainly rice and rice products that increased carbohydrate intake from $70.2 \sim 94.6 \mathrm{~g} / \mathrm{d}$ during the first 3 months of lactation. The mean intake of beans and tubers also 
increased during this period, while flour and flour products decreased (Table 2). The dietary habits and culture of inhabitants in southern Chinese usually consumed more rice and rice products; while in northern Chinese, the diet is richer in flour and flour products. Low carbohydrate diets have been used for weight control and the treatment of obesity [36]. It is therefore not a surprising finding that lactating mothers had little physical activity during their first 3 months of lactation, but their low carbohydrate diet, along with breastfeeding kept their BMI at $<24$ throughout the study. Surprisingly, the control group of women consumed only $37 \sim 43 \%$ of the recommended carbohydrate (RNI 316.3 373.8g/day), while their protein intake were $\sim 12 \%$ higher than the RNI and their fat intake were in the normal range of the recommended levels (51.1-76.7 g/day, Table 4). Their total caloric intake $(1431 \mathrm{Kcal})$ was $\sim 38 \%$ lower than the recommended daily RNI of $2300 \mathrm{Kcal}$ for women with a moderate level of physical activity (Table 4). Thus, the lower total caloric intake, resulting from the decreased carbohydrate, increased protein and the median level of fat consumption, served to keep the BMI of all control women in the normal range recommended [37]. A healthy diet enriched in fresh fruits, vegetables, cereals and grains, and low in fat, coupled with regular physical activity can help many people manage and maintain adequate health and well being and a decreased health risk from CHD. Based on our findings, it is evident that further long-term studies are required to follow up on the health and disease risks for the population of Chinese mothers and infants who do not receive the RNI recommended level of nutrients required to sustain health.

Lactating mothers should have a slightly increased requirement for most nutrients compared to women who are not pregnant or lactating, as many vitamins and minerals in a breastfeeding mother's diet are transferred into the breast milk [35]. We found in the lactating mothers however, that the intake of several important vitamins and minerals during the first 90 days of lactation were $6 \% \sim 75 \%$ lower than the RNI, including thiamine, vitamin $\mathrm{C}$, folate, calcium and zinc, as summarized in Tables 4. Thiamine and folate are important B vitamins that are involved in many cellular processes critical for healthy growth and development [38]. Vitamin $\mathrm{C}$ is an essential nutrient, and plays an important role as an antioxidant to protect the body against oxidative stress [39]. Similarly, zinc is a co-factor for many enzymes and also functions to help maintain structural integrity of proteins and to regulate gene expression [40]. Long-term deficiencies in these nutrients can have a significant deleterious impact on health, causing deficiency diseases, healththreatening conditions and some common chronic systemic diseases [41].
Similarly, we also discovered that the intake of dietary fiber in the lactating mothers was less than $1 / 2 \sim 1 / 4$ of the level recommended by the RNI during throughout study. Conversely, the intake levels of riboflavin, niacin, vitamin E, iron and selenium were $50 \%$ to 3 -fold higher than the RNI during the first 3 months of lactation, as summarized in Table 4. In humans, there is no evidence for riboflavin toxicity produced by excessive intakes, as any excess at nutritionally relevant doses is excreted in the urine [42]. Vitamin E, a fat soluble vitamin that is stored in lipophilic tissues and is also an antioxidant, appears to be relatively non-toxic in healthy adults. However, its long-term safety is questionable following results showing a possible increase in mortality and in the incidence of heart failure [43]. The high intake of niacin, iron and selenium in our subjects were likely caused by the high protein intake from animal food. Thus, the self-selected diet of lactating mothers in southeast coastal China is unbalanced and fails to meet the recommended Chinese RNI for lactating mothers. On this basis, we postulate that the long term unbalanced dietary intake may increase the potential health risks for both lactating mothers and their babies. Accordingly, we recommend that dietary fiber, thiamine, vitamin $\mathrm{C}$, folate, calcium and zinc levels should be increased in the diet of Chinese lactating women and that the total levels of niacin and selenium should be decreased by reducing fatty animal food intake. This important observation should be of concern to health care professionals charged with overseeing the health and well being of mothers and children in China. To our knowledge, this is the first systematic study to monitor and evaluate the total and complete level of food intake in lactating mothers during their first 90 days of lactation in the Southeast coastal region of China.

\section{Conclusions}

In many cases, the diet of the lactating and control group of women does not meet the Chinese RNI and, as a consequence, may have a negative impact on the quality of maternal milk and affect the potential health of mothers and infants. Nutritional education is essential for both lactating and non-lactating women. The population of China is over 1.34 billion people with 56 distinct ethnic groups. Each ethic group have their own dietary habits and cultural differences, such as northern China people prefer to eat more noodles or steam buns and hot spicy foods including chilies, onions, and garlic, while the southern Chinese people in general consume large amounts of rice and mild and cooling foods. The RNI needs to more adequately reflect the regional dietary habits and culture. A single national RNI is not applicable to all regions of China. 
Increased intake of fresh vegetables, fruits multivitamin and calcium supplements should be recommended by Chinese health officials to all women, and to those who do not consume adequate amounts of these foods and supplements. A healthy, balanced diet for lactation is important for both mother and infant in order to have a positive, long-term effect on the outcome of their health and resistance to disease. The more cross-country surveys are needed in future.

\section{Competing interests}

None of the authors have any competing interest with respect to the study.

\section{Acknowledgments}

We acknowledge the perseverance and endurance of the participants in this study, and the outstanding professionalism of the nurses who work in the Maternal and Child Care Service Centre of Xiamen, China. We thank Prof. Peter Petocz for advising in statistic analysis and comments on the manuscript. We also acknowledge the help of Dr Hongwei Li in the early stages of this study. This study was supported by a research grant from the School of Medicine, Xiamen University.

\section{Author details}

'School of Medicine, Xiamen University, Xiamen 300136, China. ${ }^{2}$ Department of Biochemistry and Molecular Medicine, University of California School of Medicine, Davis, CA 95616, USA. ${ }^{3}$ School of Molecular Bioscience, The University of Sydney, Sydney NSW 2006, Australia.

\section{Authors' contributions}

BW, conceptualized and designed the study; BW and FAT contributed to the analyses and interpretation of the results and final writing of the manuscript; HJC, PW, and JM collected the data, HJC and PW contributed to the first draft the manuscript, YFH and HJC carried out the statistical analyses. All authors read and approved the final manuscript.

Received: 2 March 2012 Accepted: 30 May 2012

Published: 16 July 2012

\section{References}

1. Gunderson EP, Jacobs DR Jr, Chiang V, Lewis CE, Feng J, Quesenberry CP Jr, Sidney S: Duration of lactation and incidence of the metabolic syndrome in women of reproductive age according to gestational diabetes mellitus status: a 20-Year prospective study in CARDIA (Coronary Artery Risk Development in Young Adults). Diabetes 2010, 59(2):495-504.

2. Stuebe AM, Rich-Edwards JW, Willett WC, Manson JE, Michels KB: Duration of lactation and incidence of type 2 diabetes. JAMA 2005, 294(20):2601-2610

3. Stuebe AM, Michels KB, Willett WC, Manson JE, Rexrode K, Rich-Edwards JW: Duration of lactation and incidence of myocardial infarction in middle to late adulthood. Am J Obstet Gynecol 2009, 200(2):e131-e138. 138.

4. Schwarz EB, Ray RM, Stuebe AM, Allison MA, Ness RB, Freiberg MS, Cauley JA: Duration of lactation and risk factors for maternal cardiovascular disease. Obstet Gynecol 2009, 113(5):974-982.

5. Stuebe AM, Willett WC, Xue F, Michels KB: Lactation and incidence of premenopausal breast cancer: a longitudinal study. Arch Intern Med 2009, 169(15):1364-1371.

6. Lonnerdal B: Effects of maternal dietary intake on human milk composition. J Nutr 1986, 116(4):499-513.

7. Scopesi F, Ciangherotti S, Lantieri PB, Risso D, Bertini I, Campone F, Pedrotti A, Bonacci W, Serra G: Maternal dietary PUFAs intake and human milk content relationships during the first month of lactation. Clin Nutr 2001 20(5):393-397.

8. Guesnet $\mathrm{P}$, Alessandri JM: Docosahexaenoic acid (DHA) and the developing central nervous system (CNS) - Implications for dietary recommendations. Biochimie 2011, 93(1):7-12.

9. Makrides M, Neumann MA, Gibson RA: Effect of maternal docosahexaenoic acid (DHA) supplementation on breast milk composition. Eur J Clin Nutr 1996, 50(6):352-357.
10. Bates CJ, Prentice AM, Watkinson M, Morrell P, Sutcliffe BA, Foord FA, Whitehead RG: Riboflavin requirements of lactating Gambian women: a controlled supplementation trial. Am J Clin Nutr 1982, 35(4):701-709.

11. Haskell MJ, Brown $\mathrm{KH}$ : Maternal vitamin A nutriture and the vitamin A content of human milk. J Mammary Gland Biol Neoplasia 1999, 4(3):243-257.

12. Hollis BW, Wagner CL: Vitamin D requirements during lactation: highdose maternal supplementation as therapy to prevent hypovitaminosis D for both the mother and the nursing infant. Am J Clin Nutr 2004, 80(6 Suppl):1752S-1758S.

13. Mulligan ML, Felton SK, Riek AE, Bernal-Mizrachi C: Implications of vitamin D deficiency in pregnancy and lactation. Am J Obstet Gynecol 2010, 202(5):e421-e429. 429.

14. Society CN: Chinese Dietary Reference Intakes. Beijing: China Light Industry Publishing House; 2006.

15. Society CN: Chinese Dietary Guidelines. 2008: Tibet People Publishing House; 2008.

16. Whitehead RG: Nutrition and lactation. Postgrad Med J 1979, 55(643):303-310.

17. Takimoto H, Yoshiike N, Katagiri A, Ishida H, Abe S: Nutritional status of pregnant and lactating women in Japan: a comparison with nonpregnant/non-lactating controls in the National Nutrition Survey. J Obstet Gynaecol Res 2003, 29(2):96-103.

18. Paul AM: How the First Nine Months Shape the Rest of Your Life:; 2010. TIME Magazine http://www.time.com/time/magazine/article/0,9171,2021065,00. html.

19. Sullivan S, Schanler RJ, Kim JH, Patel AL, Trawoger R, Kiechl-Kohlendorfer U, Chan GM, Blanco CL, Abrams S, Cotten CM, et al: An exclusively human milk-based diet is associated with a lower rate of necrotizing enterocolitis than a diet of human milk and bovine milk-based products. J Pediatr 2010, 156(4):562-567. e561.

20. Lucas A, Morley R, Cole TJ, Gore SM, Lucas PJ, Crowle P, Pearse R, Boon AJ, Powell R: Early diet in preterm babies and developmental status at 18 months. Lancet 1990, 335(8704):1477-1481.

21. Butte NF, Lopez-Alarcon MG, Garza C: Nutrient Adequacy of Exclusive Breastfeeding for the Term Infant during the First Six Months of Life. In WHO Library Cataloguing-in-Publication Data, Volume 1. Switzerland: Geneva: WHO; 2002:57.

22. Malloy $\mathrm{MH}$, Berendes $\mathrm{H}$ : Does breast-feeding influence intelligence quotients at 9 and 10 years of age? Early Hum Dev 1998, 50(2):209-217.

23. Lawrence RA: Breastfeeding: benefits, risks and alternatives. Curr Opin Obstet Gynecol 2000, 12(6):519-524.

24. Wang $L$, Kong $L$, Wu F, Bai $Y$, Burton R: Preventing chronic diseases in China. Lancet 2005, 366(9499):1821-1824.

25. Yang G, Kong L, Zhao W, Wan X, Zhai Y, Chen LC, Koplan JP: Emergence of chronic non-communicable diseases in China. Lancet 2008, 372(9650):1697-1705.

26. Institute of Nutrient and Food Safety CDC, Yang YX, Wang GY, Pan XC: China Food Composition:: Peking University Medical Press; 2009. http://www. zhuoyuewangshangshucheng.com/book/2111.html.

27. Gu D, He J, Duan X, Reynolds K, Wu X, Chen J, Huang G, Chen CS, Whelton PK: Body weight and mortality among men and women in China. JAMA 2006, 295(7):776-783.

28. Chinese Medical Association Subsection of Cardiovascular Disease: Chinese Journal of Cardiology Editorial Board. Highlights of the Second National Conference on Dyslipidemia. Chin J Cardiol 2002, 30:643-646.

29. Sun $\mathrm{CH}$ : Nutrition and Food Hygiene. 6th edition. Beijing: People's Medical Publishing House; 2007. http://baike.baidu.com/view/1442422.htm.

30. Australia Government DoHaANM: Nutrient Reference Values for Australia and New Zealand Including Recommended Dietary Intakes. In Ministry of Health. 2006. http://www.nhmrc.gov.au/guidelines/publications/n35-n36-n37.

31. St Jeor ST, Howard BV, Prewitt TE, Bovee V, Bazzarre T, Eckel RH: Dietary protein and weight reduction: a statement for healthcare professionals from the Nutrition Committee of the Council on Nutrition, Physical Activity, and Metabolism of the American Heart Association. Circulation 2001, 104(15):1869-1874.

32. Berr C, Akbaraly T, Arnaud J, Hininger I, Roussel AM, Barberger Gateau P: Increased selenium intake in elderly high fish consumers may account for health benefits previously ascribed to omega-3 fatty acids. J Nutr Health Aging 2009, 13(1):14-18.

33. Umhau JC: Docosahexaenoic acid supplementation and Alzheimer disease. JAMA 2011, 305(7):672. author reply 673 
34. Zhang J, Meng LP, Jiang YR: The dietary fatty acids intakes and their food sources among Chinese adults. Acta Nutr Sinica 2009, 31:424-427.

35. Koletzko B, Cetin I, Brenna JT: Dietary fat intakes for pregnant and lactating women. Br J Nutr 2007, 98(5):873-877.

36. Shai I, Schwarzfuchs D, Henkin Y, Shahar DR, Witkow S, Greenberg I, Golan R, Fraser D, Bolotin A, Vardi $\mathrm{H}$, et al: Weight loss with a low-carbohydrate, Mediterranean, or low-fat diet. N Engl J Med 2008, 359(3):229-241.

37. Zhou B: Prospective study for cut-off points of body mass index in Chinese adults. Zhonghua Liu Xing Bing Xue Za Zhi 2002, 23(6):431-434.

38. Singh MYM, Bajaj $\mathrm{H}$, Bisht S: Vitamins indispensible elements: today and tomorrow. Int J Comm Pharm 2011, 4(1):12-22.

39. Padayatty SJ, Katz A, Wang Y, Eck P, Kwon O, Lee JH, Chen S, Corpe C, Dutta A, Dutta SK, et al: Vitamin C as an antioxidant: evaluation of its role in disease prevention. J Am Coll Nutr 2003, 22(1):18-35.

40. Salqueiro MJ, Zubillaga M, Lysionek A, Sarabia MI, Caro R, De Paoli T, Hager A, Weill R, Boccio J: Zinc as an essential micronutrient: a review. Nutr Res 2000, 20(5):737-755.

41. Esfahani A, Wong JM, Truan J, Villa CR, Mirrahimi A, Srichaikul K, Kendall CW: Health effects of mixed fruit and vegetable concentrates: a systematic review of the clinical interventions. J Am Coll Nutr, 30(5):285-294. http:// www.ncbi.nlm.nih.gov/pubmed/22081614?dopt=Citation.

42. Zempleni J, Galloway JR, McCormick DB: Pharmacokinetics of orally and intravenously administered riboflavin in healthy humans. Am J Clin Nutr 1996, 63(1):54-66.

43. Miller ER, Pastor-Barriuso R 3rd, Dalal D, Riemersma RA, Appel L, Guallar E: Meta-analysis: high-dosage vitamin $\mathrm{E}$ supplementation may increase allcause mortality. Ann Intern Med 2005, 142(1):37-46. http://www.ncbi.nlm. nih.gov/pubmed/15537682?dopt=Citation

doi:10.1186/1472-6874-12-18

Cite this article as: Chen et al:: Evaluation of dietary intake of lactating women in China and its potential impact on the health of mothers and infants. BMC Women's Health 2012 12:18.

\section{Submit your next manuscript to BioMed Central and take full advantage of:}

- Convenient online submission

- Thorough peer review

- No space constraints or color figure charges

- Immediate publication on acceptance

- Inclusion in PubMed, CAS, Scopus and Google Scholar

- Research which is freely available for redistribution 